This item was submitted to Loughborough's Research Repository by the author.

Items in Figshare are protected by copyright, with all rights reserved, unless otherwise indicated.

\title{
No price without value: Towards a theory of value and price
}

PLEASE CITE THE PUBLISHED VERSION

https://doi.org/10.1093/cje/bez040

PUBLISHER

Oxford University Press (OUP)

VERSION

AM (Accepted Manuscript)

PUBLISHER STATEMENT

This is a pre-copyedited, author-produced version of an article accepted for publication in Cambridge Journal of Economics following peer review. The version of record ELDER-VASS, D., 2019. No price without value: Towards a theory of value and price. Cambridge Journal of Economics, 43 (6), pp.1485-1498 is available online at: https://doi.org/10.1093/cje/bez040

\section{LICENCE}

CC BY-NC-ND 4.0

\section{REPOSITORY RECORD}

Elder-Vass, Dave. 2019. "No Price Without Value: Towards a Theory of Value and Price". Loughborough University. https://hdl.handle.net/2134/38145. 


\title{
No price without value: Towards a theory of value and price
}

\author{
Dave Elder-Vass*
}

*** This is a pre-publication version of a paper to be published in the Cambridge Journal of Economics.

\begin{abstract}
The relationship between value and price, a central focus of classical political economy, has fallen into the shadows of neglect in contemporary economics. This paper builds on a critical realist framework and findings from the economics of conventions and the sociology of valuation to develop a theory of value that returns to the relation between value and price. It argues that value is best understood as a view of the price that something ought to exchange at, and that these views are shaped normatively by a host of lay theories of value and the groups and organisations that advance them. Through their effects on our assessments of value, these theories also influence the determination of prices. Although prices in open systems are determined by many interacting factors, lay theories of value play a crucial role in the process.
\end{abstract}

Keywords: conventions, lay theories of value, price, value, valuation.

JEL classification: B50, D46, L11

Address for correspondence: $\underline{\text { d.elder-vass@lboro.ac.uk }}$

Department of Social Sciences, Loughborough University, Ashby Road, Loughborough, LE11 3TU, United Kingdom.

* Loughborough University. This work would have been impossible without the generosity of the Independent Social Research Foundation in funding a Political Economy Research Fellowship. I also wish to thank Dean Curran and Olivier Favereau for their comments and Emma Greeson for several useful inputs. 


\section{No price without value: Towards a theory of value and price}

The relationship between value and price, a central focus of classical political economy, has fallen into the shadows of neglect in contemporary economics. Value has become a mantra for Marxists, who marginalise its relation to price, and anathema to the mainstream, who theorise equilibrium price without explicit reference to value. This paper seeks to rehabilitate the concept of value and to position it as one factor among many that should be taken into account in a post-marginalist theory of price determination. It thus offers a step towards a heterodox theory of value and another, perhaps smaller, step towards a heterodox theory of price.

Since at least the time of Marx, academic theories of economic value have obscured rather than clarified the concept of value and as a result they have undermined its use in understanding monetary exchange. But this confusion has not arisen because the ontology of value is impossibly difficult to fathom. Nothing could be further from the truth. Indeed, I argue, the nature of economic value is so close to the surface of lay discourse that it may appear trivial once it has been grasped: the economic value of a thing is the price it ought to exchange at. When we talk about the value of something in the context of exchange we are talking about what it is worth, about what a fair price for it would be. Each of us makes our own estimation of the value of a thing, but there are social forces that tend to regulate those estimations. Value is thus normative - doubly normative, as it is influenced by assessment of what is a just price, and these assessments themselves depend on social norms about valuation. It is also ontologically subjective in the sense proposed by John Searle (Searle, 1995, p. 10) and socially constructed, and integrating it into price theory requires an ontologically sensitive synthesis of sociological and economic thinking.

This paper begins by introducing the notion of value as a normative concept, then differentiates the proposed theory of value from those espoused by Marx and the marginalist tradition in economics. This brings us to alternative approaches to price theory, which are positioned in an extended realist ontological framework for explanation in open systems (cf Lawson, 2003). The paper then elaborates 
the proposed approach to value by building critically on contributions from the economics of conventions and the sociology of valuation. It closes by reviewing how far this takes us towards a more adequate theory of price.

\section{Value is a normative concept}

It is generally accepted that the economic concept of value bears some relationship to the concept of price, although the nature of that relation is controversial. Boltanski and Esquerre for example, write that value "serves as the justification for prices" (Boltanski \& Esquerre, 2016, p. 37) (also see Aspers \& Beckert, 2010, p. 8). As Boltanski puts it, "Value talk only happens in situations in which there is a problem with the price... So what is the function of 'value'? It is the justification of the price, plain and simple" (Boltanski, Esquerre, \& Muniesa, 2015, p. 78). The implication is clear: value is a normativised expectation about price, an expectation about the price that an item ought to sell at. Of course, there may be many different views of what that price should be, and many different arguments to consider in judging it. But to say that the value of a thing is defined in this way does not mean that there is only one price that is its value for everyone. It simply means that when a lay actor holds a belief or makes a statement about the economic value of a thing, it is a belief or statement about the price it ought to exchange at. Here the term ought denotes an ethical claim, strongly related to questions of fairness in exchange or just price.

In the Western academic tradition, early discussions of value such as those in Aristotle and Aquinas adopted this notion of the just price as the standard of value (Heilbroner, 1988, pp. 108-9; Mirowski, 1991, II. 2384, 3108). This concept did not denote a single fixed price, but rather "the outcome of a myriad of imponderable considerations tethered to the individual case and the specific context" - a "reflection of social relations" (Mirowski, 1991, I. 2384). This notion of the just or reasonable price, however, was not merely academic, but rather was embedded in lay discourse and practice. This is brilliantly illustrated in E.P. Thompson's classic paper on food riots in eighteenth century England, 
showing that they were generally responses to soaring food prices. Frequently these "riots" took the form of crowds insisting that farmers, millers, bakers or merchants sell their stocks at what the crowd considered a fair price, "a traditional 'moral' price set by the crowd" (Thompson, 1971, p. 126). This price might vary from time to time and place to place, but it was a price at which the working poor could afford to feed their families, a price that reflected the social entitlement to a reasonable subsistence that they saw as the moral counterpart to their role in the economy (also see Hann, 2010, p. 190).

This is a doubly normative conception of economic value. On one hand, value is normative in the sense that the principles employed in assessing fair value are social norms: they are largely learned from social interaction and influenced by normative pressures about what ways of valuing things are appropriate. On the other, it is normative in the ethical sense that it is a belief about the fair or just price of a thing. This ethical dimension of economic value, however, does not collapse economic and other concepts of value into each other. Non-economic valuations of things or services, for example on aesthetic grounds, may contribute to our assessments of their economic value, but these are nevertheless assessments against different standards. What is distinctive about economic value is that it is an assessment of the fair price of a thing against a monetary standard of exchange.

Each of us makes our own estimation of the value of a thing, but there are also social forces, discussed below, that tend to regulate and standardise those estimations. Those forces also, as an incidental by product, encourage the belief that there might be one true objective value of any given thing. Since Marx and perhaps earlier, economists have adopted that belief and developed theories that seek to explain the objective values of things.

\section{Marx and value}

In stark contrast to the argument above, Marx insisted that value is not normatively based, not socially constructed, not subjective or even intersubjective, but rather an objective property of a product of 
labour: the quantity of socially necessary labour time required to produce it (Marx, 1954, p. 47). I do not propose to explain Marx's labour theory of value in detail here (for a brief explanation of the key features see Elder-Vass, 2016, pp. 61-63), or to provide a full critique of it (see Elder-Vass, 2016, pp. 64-69). But Marx's theory has played a crucial role in understandings of value, particularly among those with critical inclinations, and it is important to clarify some of the ways in which the theory proposed here differs from Marx's.

The issue that is most relevant to my argument is the relation between Marx's concept of value and the concept of price. Marx insists that value is distinct from price (Marx, 1954), but if value is not the same thing as price, we are entitled to ask what exactly value is. Marx gives us a theory of what determines the exchange value of an object - the amount of socially necessary abstract labour required to produce it - but without an indication of how value might appear as an empirical phenomenon in its own right, exchange value has no other meaning in this system than the amount of labour required to produce the commodity. To say that this is determined by the amount of labour required is circular. Marx did attempt to find a way to reconcile his theory of value with a theory of price, in his work on the transformation problem (Marx, 1959, Chapters VIII-X), but his failure to publish this work in his lifetime suggests that he never resolved the issue to his own satisfaction. Nevertheless, this attempt does suggest that he saw the theory of value and thus the concept of value as having an explanatory role in a theory of actual prices.

It is possible that Marx did not see this as a problem because he took for granted a sense of the relationship between price and value that was already in general circulation. As Mirowski explains, it was common "to postulate a distinction between intrinsic value, naturally determined and fundamentally stable, and market price, an epiphenomenon of the myriad conjunctures of the historically specific market" (Mirowski, 1991, I. 3259). It seems likely that this discursive framing of value informed Marx's thinking, so that there is a sense in which value (perhaps adjusted for profit equalisation as his discussion of the transformation problem suggests) was taken to equate to the 
normal or equilibrium price of a commodity. Orléan tells us something similar: "Classical economists... think of value not as something associated with prices, as they are fashioned by market forces at each instant, but instead as a regulative concept that governs their movement over the longer term" (Orléan, 2014, p. 47). If this were so, it would seem meaningful to say that value, as normal price, is determined non-circularly by the socially necessary quantity of labour, even though actual prices may deviate in the short term for a variety of reasons. Indeed in places it seems that value does correspond in Marx's system to some sort of notion of normal price (Mirowski, 1991, p. 177). However, this does not solve the problem, except in a world of very stable prices, because we would now need to specify the concept of a normal price in empirical terms - is it, for example, an average price? Over what period? In what geographical space? In practical terms this solution generates more questions than it answers. Ultimately, then, Marx's concept of value has no clear empirical referent. .

\section{Marginalism and value}

The marginalist revolution in economics, which continues to provide the basic framework of mainstream economics, was at least in part a reaction against Marxist and other classical theories of value, although the word value itself is rarely used in the marginalist tradition. Marginalists tend to see value as nothing more than a synonym for price (e.g. Varian, 2010, p. 27) and value theory as nothing more than "a synonym for price theory" (Mirowski, 1991, I. 3013). The core argument of marginalism is that both demand and supply are sensitive to price and hence that price and quantities will adjust to eliminate any imbalances between the two until price reaches an equilibrium level. Although it thinks of demand as influenced by subjective factors, it is again an objectivist theory of price or value in the sense that, like Marx's, it sees value, now understood as equilibrium price, as one quantity that is the same for all market participants for any given product. Granted, that quantity may vary dynamically over time, but at any one time it is taken to be set at one and the same level for all participants by 
market forces rather than being particular to an individual, and the marginalist theory is seen as a scientific theory of the processes by which it is set.

But although it is presented, even today, as a theory of price, the marginalist theory is really a theory of price as an ideal rather than as an empirical phenomenon. Let me return to a quote I used earlier but extend it a little: "Classical economists... think of value ... as a regulative concept that governs [price] movement over the longer term. In Walras, equilibrium price similarly functions as a norm" (Orléan, 2014, p. 47). In many commodity exchanges it is implausible to see the actual price that is paid for an item as an equilibrium price for a market as a whole. At any one time, we will often find different people paying different prices for equivalent items and there are often systematic forces maintaining price differentials for the very same product (Elder-Vass, 2016, p. 77; Kirman \& Vriend, 2000). Identical pieces of furniture, for example, may be on sale at radically different prices at stores oriented to different demographics within a few miles of each other. If there is such a thing as an equilibrium price here, it cannot be the actual prices being paid, but once again some sort of regulative concept: a notional price at which marginalist theory says goods ought to exchange. While Marx had a theory of value as a non-empirical phenomenon distinct from actual prices, the marginalists, ironically, have a theory of price as a non-empirical phenomenon that is distinct from actual prices. No doubt many mainstream economists have moved beyond the cruder versions of marginalism, but the mainstream can be challenged on these grounds whenever it continues to pursue formalisations that rest on the assumption that price equilibrium is achieved.

\section{Price in an open economic system}

An adequate theory of price would look very different from the marginalist model, in particular because the sort of causal closure it implies, in which atomistic agents are isolated from other causal factors, rarely (if ever) occurs in the social realm (Lawson, 2006, pp. 494-497). Real economic systems are open systems and events that occur in open systems are influenced by multiple causal 
mechanisms or powers which may interfere with each other and alter each other's effects (Faulkner, 2007). As has been argued at length elsewhere, we need a critical realist ontological framework to account for causal processes in such systems (Elder-Vass, 2010; Lawson, 2003). For the purposes of this paper we may focus on a subset of the framework:

a) actual events are the outcome of multiple interacting causal powers (Bhaskar, 1975, pp. 110-111; Elder-Vass, 2010, p. 47)

b) causal powers are produced by mechanisms: repeatable processes that depend on the structure and composition of the entities possessing the power concerned (Elder-Vass, 2012, pp. 17-18)

c) because events are the outcome of multiple interacting powers, individual causal powers do not produce exceptionless empirical regularities but rather tendencies for a given type of outcome to follow, tendencies that may be defeated by other interacting causal powers (Fleetwood, 2001);

From this it follows that explanation in the social sciences should aim to identify the causal powers that interact to produce social events, and that this requires us to conduct two related explanatory processes, known as:

i) retroduction: a movement "from a conception of some phenomenon of interest to a conception of some... type of thing, mechanism, structure or condition that, at least in part, is responsible for the given phenomenon" (Lawson, 1997, p. 24). I take this to require the identification and explanation of the mechanism that produces a given type of causal power (Elder-Vass, 2010, p. 48); and ii) retrodiction, which entails the identification of the set of causal antecedents to states of affairs (Lawson, 1997, p. 221), or more specifically the identification of the set of causal powers that interacted to produce an event (Elder-Vass, 2010, p. 48). As Bhaskar puts it "To completely account for an event would be to describe all the different principles involved in its generation". However, he goes on to say that "A complete explanation in this sense is clearly a limit concept" and in practice it is only 
viable to consider the most significant contributions to any given event or type of event (Bhaskar, 1975, p. 111).

Taken literally, retrodiction seems to suggest that we should spend our time constructing detailed explanations for every single event of interest to us; in practice, however, this too is a limit concept. While it may sometimes be necessary to conduct detailed investigations of individual cases, we can often perform what I propose to call retrodictive generalisation. This is the relatively familiar explanatory practice of identifying the common causal factors to be found across a group of cases that are in some way related. Good explanatory work, however, also requires what I propose to call retroductive generalisation: when we have identified a specific mechanism, we will often find that it is a particular concrete variation of a more abstract but more widely occurring mechanism. Both of these concepts will prove useful below.

\section{Heterodox accounts of price}

In this explanatory context, some of the mechanisms theorised in the marginalist tradition may remain relevant (Elder-Vass, 2016, pp. 78-81). Price setting may be affected, for example, by concerns over the effect on demand of raising them too high, or the availability of substitutes. But these are only a small subset of the causal factors influencing pricing, and factors that may be undermined by others. For example, many producers are able to insulate themselves from the comparative pricing effect by developing preferential attachment in their customers (Callon, Méadel, \& Rabeharisoa, 2002; Chamberlin, 1956, pp. 56-7, 71). Apple, for example, uses its marketing to create a sense that its products are cooler and more usable than the alternatives and as a consequence is able to sell them at a higher price than competing products (Elder-Vass, 2016, pp. 123-129; McGuigan, 2009, p. 124). Heterodox economics has had relatively little to say about price, the main exception being work in the post-Keynesian tradition. Post-Keynesians argue that prices are not adjusted constantly in response to market forces, or determined by marginal costs of production, but instead set by producers "in advance of trade" by adding a mark-up to average costs of production (Downward \& Lee, 2001, p. 
474). They then adjust the price only rarely and usually in response to cost changes. At least some post-Keynesians also recognise that pricing occurs in open systems where many causal forces interact, and therefore other factors must also be taken into account (Downward \& Lee, 2001, p. 473). We must, for example, ask what determines the mark-up, and the changes in prices when they do occur. These arguments work well as a critique of marginalist theories of price equilibration by identifying an important class of cases where equilibration does not occur, or is at best an occasional influence. They are, however, only a partial alternative to marginalist price theory. One reason is that the theory applies in some cases but not in many others. Stable cost plus pricing may be the norm for manufacturing producers, but it is not for financial assets, auctions, large retail businesses with strong competitors, stock clearance, products made to fulfil one-off negotiated orders, automated pricing on sites like amazon.com, state regulated prices, fine art showrooms, or prices subsidised as loss leaders, for example.

The strength of the open systems framework, however, is that it creates space for us to take account, not only of these relatively familiar mechanisms, but also a broad range of others, and this paper's argument is that a significant set of those mechanisms are best explained using a reframed theory of value. In developing such a theory, I aim to retroduce one generalisable mechanism that must be taken into account in a vast range of retrodictive explanations of specific price outcomes.

\section{Lay theories of value}

This paper proposes that we need a second-order theory of value, a theory of theories of value -not a theory of academic theories of value but rather an academic theory of lay theories of value, the theories of value that are actually deployed by social actors in valuing items (which may sometimes include first-order academic theories: see MacKenzie, 2006).

This involves seeing economic value in its everyday sense as the quantity of money that a thing ought to exchange for. Rather than an objective quantity, value is subjective in the sense that different 
people may have different understandings of the value of a thing, but this is not the subjectivity of the isolated atomistic individual of neoclassical theory. Rather, it is a subjectivity that is also social in the sense that individual judgements of value are shaped by intersubjective cultures of valuation (Aspers \& Beckert, 2010, p. 24). Those cultures in turn take the more specific form of lay theories of value. Different theories of value, sometimes complementary and sometimes contradictory, may be advocated or supported by different and overlapping groups of people and the extent of their influence is a product of discursive struggles into which powerful actors invest considerable resources (cf norm circles: Elder-Vass, 2010, Chapter 6).

There are many such theories and they are often (though not always) relatively simple, which is perhaps one reason they tend to fall under the academic radar. Unlike objectivist theories of value they are typically partial in the sense that each addresses only one of the multiple factors that influences the value of a thing. Thus, for example, one common theory of value is that an item that is sub-standard, perhaps because it was constructed defectively, it has been damaged, it has deteriorated over time, or it requires repair, should cost less than an equivalent item of the expected standard of quality. Another, and one that has been produced by many years of discursive work by the producers of 'luxury' goods, is that an item that is associated with higher social status, such as a designer handbag, should cost more than one without such associations.

Generally, the act of valuing a particular thing will involve taking into account a number of these theories, rather than just one, and the mix of theories that a given actor employs in a given case will depend on a number of further factors, such as the characteristics of the item to be valued, the context in which the valuation is done, and the previous social experience that has influenced which theories the actor is attached to. One consequence is that there can be wide variations between different people's assessments of value, and indeed the empirical evidence supports this (Zuckerman, 2012, p. 224). But the view advanced here also implies that we should routinely expect multiple theories of value to be in play for each actor. Hence a second-order theory of value should pay 
attention to what factors influence the set of theories of value that is brought to bear by each actor in any given case and what affects the weightings that actors give to them. This is the retrodictive moment of the explanation.

But such a theory will also need to examine those lay theories themselves and how they come to be accepted by economic actors in the first place. This is the social constructionist element of the theory and also one of the retroductive moments of the explanation, identifying specific causal mechanisms behind assessments of value and how they operate. Value is socially constructed in the sense that it depends on the shared theories of value that actors believe in and employ, and because there are powerful social influences on which theories they accept. The social construction of value, I should stress, is entirely consistent with theories of value being causally significant and thus real (Elder-Vass, 2012). It is also entirely consistent with there being objective material factors that actors take into account in the process of valuation (Zuckerman, 2012, p. 227).

No second order theory of value can encompass all possible lay theories of value and all their various applications, and extensive examination of possible theories and applications is beyond the viable scope of this paper, although it will consider some examples in the 'Valuation as a process' section below to illustrate the theoretical framework. What this paper does take a step towards, however, is retroductive generalisation: to identify common features of different theories of value and hypothesise the more abstract form of lay theories of value in general.

\section{Conventions}

The concept of lay theories of value has a great deal in common with the concept of conventions, as understood by the French school of the economics of convention, which has been developing since the 1980s. This tradition began by focussing on the ways in which judgements were made of the nature and value of things by employing socially sanctioned general principles or "socio-cultural logics" that they call conventions, although they are also referred to by different authors as "orders of 
justification, quality conventions, or worlds of production" (Diaz-Bone, 2017, p. 241). The earliest work in the tradition considered how people classify others into socio-professional categories (Jagd, 2007, p. 76). This kind of judgement about how to categorise people or things has come to be known as qualification, and one of the important findings of the conventions school is that this is a key element of market processes. The notion of a market depends on the idea that different products are comparable, and the process of qualification identifies which class of products a particular item should be compared with, using what Desrosières calls "conventions of equivalence" (Diaz-Bone, 2017, p. 242). Conventions are collectively shared standards or rules about how to make judgements, which emerge and develop in the process of making judgements but tend to become widely accepted to the point where they are taken for granted by the actors (Diaz-Bone, 2017, p. 245).

Perhaps the most influential work in this tradition is Boltanski and Thévenot's book On Justification (2006) which extends the theory of conventions to the broader sociological question of how people make judgements and resolve disagreements in all manner of social disputes about the "qualities and worth of objects, actions and persons" (Diaz-Bone, 2017, p. 245, fn 11). The authors argue that people use a range of forms of justification that they call "orders of worth", which invoke quite different kinds of values, and that many social disagreements are in effect disputes about which order of worth applies to a given question. Each order of worth, however, is a relatively well established set of social norms, flowing from a larger, broader principle. They identify six "worlds", each governed by a different order of worth, including for example the civic world, where the higher common principle is commitment to collectives and the collective good (Boltanski \& Thévenot, 2006, p. 185) and the industrial world, whose higher common principle is efficiency (Boltanski \& Thévenot, 2006, p. 204) . Conventions are intersubjectively normative (Favereau, 2008) and there is thus a parallel between what I have called lay theories of value and the theory of conventions. However, there may also be differences. One concerns the question of field. Rather than economic value, Boltanski and Thévenot apply the tradition to broad questions of justification in disputes between people, and most of the 
economic applications apply conventions to the question of how the qualities of things are categorised - to questions, on might say, of use value rather than exchange value (Favereau, 2017). But there are other thinkers in the tradition who do apply the notion of convention to monetary valuation, in particular André Orléan, who has recently applied the economics of conventions to financial markets (Orléan, 2014). For example, the US Internet bubble that burst in 2000 was based on the convention that Internet companies could be valued on the basis of the number of visitors they attracted to their web sites, in the belief that they would eventually be able to find a way to make money from those visitors, and this convention was used to value even companies that were making a substantial loss and had no clear plan for turning this into a profit. For some time this worked as a pricing theory because many investors accepted it, but eventually enough investors lost faith in this convention to cause the price of Internet stocks to drop, and once others realised that the convention was no longer holding the bubble burst and prices tumbled dramatically (Orléan, 2014, p. 228) (also see Cassidy, 2002).

Another and perhaps more decisive divergence between conventions and lay theories of value is over the question of granularity. Boltanski and Thévenot's orders of worth are complex normative regimes organised around a central theme or principle whereas lay theories of value are single norms about price. But it is not clear whether we should define conventions by the example of orders of justification, or see those orders as only one variety of convention. In the latter case, we could also have conventions at lower levels of granularity which might approach the case of lay theories of value, and Orléan arguably takes a step in this direction, but this is not the usual way of deploying the concept of conventions.

This is apparent in the other prominent recent application of conventions theory to the question of monetary valuation: Boltanski and Esquerre's work on what they call the enrichment economy. They argue that the appeal of luxury goods "stems from a kind of aura surrounding them, signifying that they are exceptional, the property of the elite" (Boltanski \& Esquerre, 2016, p. 33), and that this aura is 
increasingly constructed though a process of "heritage creation", including "the fabrication of more or less fictional histories" (Boltanski \& Esquerre, 2016, p. 34) that enrich the objects concerned, in the sense of increasing their values. The value of these objects then comes to depend on "their accompanying narratives and genealogical reconstructions" (Boltanski \& Esquerre, 2016, p. 44). Rather than investigate the specific theories of value at work here, however, they focus on macrosocial paradigms of value that they call 'forms', identifying a new 'collection form' that operates in the economy of enrichment by contrast to the 'standard form' of the industrial economy and the 'asset form' of the financial economy (Boltanski \& Esquerre, 2016, p. 37). One reason, then, to distinguish lay theories of value from valuation conventions is to make clear that they operate at a much more detailed level of granularity than most (though not necessarily all) applications of conventions theory. A third possible divergence, which may follow from the differences in granularity, is that conventions theorists tend to take the view that a single convention is primary with regard to any given outcome, and although different actors may deploy different conventions, negotiation is generally a contest over which will apply, rather than a balancing of different conventions (Boltanski \& Thévenot, 2006). For Boltanski and Thévenot, for example, disputes are normally resolved by all parties accepting a single principle of justification, and although compromises are possible, they regard them as fragile and by implication as unusual (Boltanski \& Thévenot, 2006, pp. 277-278). By contrast, I argue that multiple lay theories of value may interact even in the formation of a single actor's assessment of value, and yet more in processes of negotiation, and it is common for many of them - as well as other causal factors - to have an influence on price outcomes.

Bearing in mind these possible differences, the economics of conventions supplies important resources for constructing a theory of economic value. One of these is the concept of reality tests: "Reality tests ... settle disputes about qualities and worth of objects, actions, and persons" (Diaz-Bone, 2017 , p. 245 , fn 11). In the context of their work, a reality test is the resolution of a dispute which settles which order(s) of worth are to govern its outcome (Boltanski \& Thévenot, 2006, p. 40). In our 
context, agreeing a price is a reality test, a test that determines which lay theories of value have most influence on a particular price (Boltanski \& Esquerre, 2016, p. 37).

\section{Prices}

The term price, however, is ambiguous. On one hand, the term is often used to mean realised price: the amount that is actually paid in a purchase transaction. On the other, it is also used to mean offer price or ticket price (Aspers \& Beckert, 2010, p. 27). In a way, the term price is a misnomer for the latter concept, because price tickets are actually a form of value claim, supported by a lay theory of value that is particularly strong in contemporary economies: the theory that the price on a ticket is the price that ought to be paid. In most supermarkets, for example, this theory reigns supreme and in many countries it is almost unheard of for a customer to seek to negotiate the ticket price in a supermarket. Yet in other settings, price tickets are recognised as merely an opening step in a process of negotiation of the value of the item (in the UK this includes second hand car showrooms, although even here price negotiation is in retreat), and in others there are no price tickets at all. This also illustrates another important point about lay theories of value: their contextual specificity. Like other kinds of norm, a theory of value that applies in one situation may not apply in others, and social actors are expected to understand the contextual parameters of theories of value.

Multiple theories of value may influence the process of exchange in at least two different ways. First, they may inform the parties' attitudes to the price without being explicitly articulated. For example, I may be presented with the opportunity to buy a certain item at price $p$, conclude on the basis of my own theories of value that the item is too expensive, and decide not to buy it at all (or indeed decide it is cheap or fairly priced and proceed to buy it without further debate). But there is a second possibility: one or other of the parties may enter into a negotiation over the price, deploying theories of value to justify a higher or a lower level. The buyer may say, for example, "this price is too high because the product is damaged" and the seller may either reply within the terms of the same theory of value, e.g. "actually those marks are not damage but a sign of the high quality of this item" or by 
deploying a different theory, e.g. "but you are lucky this is already so cheap because this product is very rare". This does not necessarily lead to a single theory of value being accepted by all parties to the negotiation. Rather, various theories may all influence the outcome to various degrees, depending for example on the strength of attachment of the actors to them, their bargaining positions, familiar economic issues such as costs of production and alternative offers available, and the discursive strength of the theories being advocated (and thus the likelihood of the theory being accepted as legitimate by the other party). Prices, to put it another way, are multiply determined by many interacting causal factors, and not just by theories of value, but the theories of value held by both buyers and sellers make an important contribution to the process of agreeing prices and to decisions about whether or not to buy.

\section{Valuation as a process}

In recent years, economic sociologists have also become increasingly interested in valuation. Like the economics of conventions, which it draws upon, this work sees monetary valuation as sharing features with other forms of valuation (Helgesson \& Muniesa, 2013, p. 2).

Some of the most useful work in valuation studies has picked out standards of value that are quite specific to particular types of commodity, although without labelling them lay theories of value or placing them within an explicit causal framework like that advocated here. For example, in a study of Dutch fiction book prices Franssen \& Velthuis show that "consumers do not see prices as neutral outcomes of supply and demand and actively judge the fairness of prices against different social standards or orders of worth" (Franssen \& Velthuis, 2016, p. 367). In the case of fiction books, it seems, what matters is not the aesthetic assessment of the writing, but rather the materiality of the book: "when it comes to prices, what is fair is intricately related to what is visible in terms of material properties of books" - customers expect to pay more for hardbacks, and more for larger format books and books printed on higher quality paper (Franssen \& Velthuis, 2016, p. 377). In my terms, this is a 
retrodictive generalisation: the theory that the price of a book should reflect its material properties appears as a mechanism across a range of similar cases. There is also a sense here that lay valuation theories are strongly sensitive to what seems fair in terms of the wider normative background.

Perhaps size and material quality are taken as indicators of the investment that publishers have made in a book - the cost of production - and thus the price it is fair for them to charge, although in fact differences in size and material quality make a relatively small contribution to the cost of production. This hypothesis is a retroductive generalisation: the theory that the price of a book should reflect its material properties has been repositioned as a case of a more abstract lay theory of value, the theory that prices should reflect the cost, or at least the apparent indicators of cost, of a product.

There is also a considerable amount of work on the valuation of what we may loosely call luxury goods or status goods. Since Veblen's work on conspicuous consumption over a century ago it has been widely recognised that some goods are purchased in order to signal the high status of the purchaser rather than because of any inherent quality of the goods themselves (Veblen, 1970). In such cases the theories of value employed by the participants are very different than those employed for what Aspers calls "standard goods" (Aspers, 2009). Aspers argues that buyers and sellers of status goods value them on the basis of each other's identities - so that a high status art dealer, for example, can demand a higher price for an artwork because of her status (Aspers, 2009, pp. 116-7). More generally, Karpik has identified a series of mechanisms used to assess the quality - and thus the value - of what he calls "singular goods", including the role of personal networks, of third party experts such as critics and guidebook writers, published rankings, and appellations - quality indicators granted by independent third parties like those attached to bottles of wine (Aspers \& Beckert, 2010, pp. 19-22). Ultimately, however, most of these mechanisms reflect a single more abstract theory of value (revealed by retroductive generalisation): that goods which enhance the apparent status of the purchaser should be valued more highly. 
Still, there is also a further level of retroductive abstraction to which we can move: the concept of lay theories of value itself, as a general form. Although relatively narrow empirical studies are extremely valuable, no single study provides, on its own, the basis for theorising at this more general level. Retroductive abstraction gives us these more general theoretical constructs and enables us to deploy them across a wider range of cases. This, arguably, is the central purpose of theoretical explanation, and the feature of science upon which Bhaskar constructed the original argument for critical realism (Bhaskar, 1975).

The field of valuation studies, then, and its cross-fertilisation with the theory of conventions, has provided rich resources for studying contemporary theories of value. We must also, however, look beyond the processes in which theories of value are deployed to the social forces that shape those theories of value in the first place. There is a politics of valuation in which certain economic actors, typically organisations, exert substantial power over valuation processes by influencing the predominant theories of value that we deploy and how we select the theories we apply to any given product (Aspers \& Beckert, 2010, p. 23). We find similar themes in the conventions tradition: "The politics of quantification and its critique is... the politics of choosing and thereby controlling the introduction and application of conventions and standards in markets and economic organizations" (Diaz-Bone, 2017, p. 248), and indeed the concept of valuation power (Eymard-Duvernay, 2011).

Often the organisations that produce and/or sell goods are able to exert significant power over this process, most obviously through advertising and marketing, but also for example by influencing discourses related to the value of their products in the media (Aspers \& Beckert, 2010, p. 15; Beckert, 2016, p. 14). Many industries have also developed an infrastructure of supposedly independent third parties to bolster the theories of value that relate to their products. In art purchases, for example, Bourdieu (1993) "emphasizes the role of critics and evaluators" in shaping assessments of the symbolic value of cultural goods (Lamont, 2012, p. 207) and their views on symbolic value strongly influence the economic value of those goods (Boltanski \& Esquerre, 2016, p. 47). In this context, and 
no doubt many others, one very powerful theory of value is that products that are endorsed as having high cultural value by those who are consecrated as experts in the field should have a higher price. Theories of value, in other words, are the constant target of a vast infrastructure generated primarily by sellers to bias and exploit valuations to their own advantage

\section{Conclusion}

The price of something, then, is always the product of many interacting causal factors, powers, or mechanisms. Contributing factors may include many that are not addressed directly in this paper but they also include the broad range of theories of value employed by both buyers and sellers to make, justify and negotiate decisions about the price to be paid. Each of these, in turn, is the product of a range of other factors. Nor are they all neatly balanced out by equilibrating forces - prices rarely if ever find equilibria and the tendencies that maintain price differentials are often just as strong as or stronger than those that produce tendencies towards price convergence. While the list of contributing factors includes some that are recognised in mainstream economic theory, this does not commit us to a mainstream view, since without a commitment to price equilibration these factors no longer have a determinative role, but act merely as one group of causes amongst others.

The focus of this paper has been on the important contribution made by lay theories of value. This does not mean, however, that price can be reductively explained in terms of theories of value, which remain only one group of factors among the larger set. Nor does it mean that value itself is an objective quantity, a number that can be determined scientifically if only we have the right theory. This paper has argued that we need to think about the concept of value very differently. The value of a thing is not an objective quality, but rather the price that it ought to exchange at, and this is a subjective quantity in the sense that different individuals may take different views of it, but also a socially constructed quantity in the sense that in doing so they draw on socially or intersubjectively shared lay theories of value. The study of value needs to examine how these theories then feed into 
processes of determining prices and making exchange decisions, but we must also examine the shaping of these theories themselves and of beliefs about when and in what circumstances they apply. At the academic level, this gives us a single second-order framework for thinking about economic value: value claims are claims about what prices ought to be, supported by lay theories of value. At the lay level, however, there is a vast sea of theories that are deployed and contested in negotiations over price. Economists may regret the loss of a neat theory of price or value that can be converted into formulae and ambitious predictions, but if the economy does not fit those neat theories we will have to learn to live with messier theories that demand different methodological approaches. This approach, nevertheless, leaves scope for the identification of important although partial regularities in the ways in which theories of value impact upon price formation, through the forms of theoretical work that I have called retrodictive and retroductive generalisation.

Many factors contribute to the determination of prices, but no price is viable unless it can be justified by the social actors involved. There is, in other words, no price without value.

\section{References}

Aspers, P. (2009). Knowledge and valuation in markets. Theory and Society, 38(2), 111. https://doi.org/10.1007/s11186-008-9078-9

Aspers, P., \& Beckert, J. (2010). Value in Markets. In J. Beckert \& P. Aspers (Eds.), The Worth Of Goods (pp. 3-38). New York: Oxford University Press, U.S.A.

Beckert, J. (2016). Imagined Futures. Cambridge, Massachusetts: Harvard University Press. Bhaskar, R. (1975). A realist theory of science (1st ed.). Leeds: Leeds Books.

Boltanski, L., \& Esquerre, A. (2016). The Economic Life of Things. New Left Review, (98), 31-54.

Boltanski, L., Esquerre, A., \& Muniesa, F. (2015). Grappling with the economy of enrichment. Valuation Studies, 3(1), 75-83. https://doi.org/10.3384/VS.2001-5592.153175 
Boltanski, L., \& Thévenot, L. (2006). On justification: economies of worth. Princeton: Princeton University Press.

Bourdieu, P. (1993). The Field of Cultural Production. Cambridge: Polity Press.

Callon, M., Méadel, C., \& Rabeharisoa, V. (2002). The economy of qualities. Economy and Society, 31(2), 194-217. https://doi.org/10.1080/03085140220123126

Cassidy, J. (2002). Dot.Con. London: Allen Lane.

Chamberlin, E. (1956). The theory of monopolistic competition (7th ed.). Cambridge, MA: Harvard University Press.

Diaz-Bone, R. (2017). Classifications, Quantifications and Quality Conventions in Markets. Historical Social Research, 42(1), 238-262.

Downward, P., \& Lee, F. (2001). Post Keynesian Pricing Theory 'Reconfirmed'? A Critical Review of 'Asking about Prices'. Journal of Post Keynesian Economics, 23(3), 465-483.

Elder-Vass, D. (2010). The Causal Power of Social Structures. Cambridge: Cambridge UP.

Elder-Vass, D. (2012). The Reality of Social Construction. Cambridge: Cambridge UP.

Elder-Vass, D. (2016). Profit and Gift in the Digital Economy. Cambridge: Cambridge UP.

Eymard-Duvernay, F. (2011). Le travail dans l'entreprise: pour une démocratisation des pouvoirs de valorisation. In R. Baudoin (Ed.), L'entreprise, formes de la propriété et responsabilités sociales (pp. 162-226). Paris: Éditions Lethielleux.

Faulkner, P. (2007). Closure. In M. Hartwig (Ed.), Dictionary of critical realism (pp. 56-57). Abingdon: Routledge.

Favereau, O. (2008). The Unconventional, but Conventionalist, Legacy of Lewis's "Convention". Topoi, $27(1-2), 115-126$.

Favereau, O. (2017). Hommage à François Eymard-Duvernay. Revue Française de Socio-Économie, (18), 5-12. https://doi.org/10.3917/rfse.018.0005

Fleetwood, S. (2001). Causal Laws, Functional Relations and Tendencies. Review of Political Economy, 13(2), 201-220. 
Franssen, T., \& Velthuis, O. (2016). Making materiality matter. Socio-Economic Review, 14(2), 363-381. https://doi.org/10.1093/ser/mwu025

Hann, C. (2010). Moral Economy. In K. Hart, J.-L. Laville, \& A. D. Cattani (Eds.), The Human Economy (pp. 187-198). Cambridge: Polity Press.

Heilbroner, R. L. (1988). The Problem of Value. In Behind the Veil of Economics. New York: Norton.

Helgesson, C.-F., \& Muniesa, F. (2013). For What It's Worth. Valuation Studies, 1(1), 1-10. https://doi.org/10.3384/vs.2001-5992.13111

Jagd, S. (2007). Economics of Convention and New Economic Sociology: Mutual Inspiration and Dialogue. Current Sociology, 55(1), 75-91. https://doi.org/10.1177/0011392107070135 Keynes, J. M. (1973). The General Theory of Employment, Interest and Money. London: Macmillan.

Kirman, A. P., \& Vriend, N. J. (2000). Learning to Be Loyal. A Study of the Marseille Fish Market. In D. D. Gatti, M. Gallegati, \& A. P. Kirman (Eds.), Interaction and Market Structure (pp. 33-56). Springer Berlin Heidelberg.

Lamont, M. (2012). Toward a Comparative Sociology of Valuation and Evaluation. Annual Review of Sociology, 38(1), 201-221. https://doi.org/10.1146/annurev-soc-070308-120022

Lawson, T. (1997). Economics and reality. London: Routledge.

Lawson, T. (2003). Reorienting economics. London: Routledge.

Lawson, T. (2006). The nature of heterodox economics. Cambridge Journal of Economics, 30(4), $483-$ 505. https://doi.org/10.1093/cje/bei093

MacKenzie, D. A. (2006). An engine, not a camera: how financial models shape markets. Cambridge, Mass.: MIT Press.

Marx, K. (1954). Capital, Volume 1. London: Lawrence \& Wishart.

Marx, K. (1959). Capital, Volume 3. London: Lawrence \& Wishart.

McGuigan, J. (2009). Cool Capitalism. London: Pluto Press.

Mirowski, P. (1991). More Heat than Light. Cambridge University Press. 
Orléan, A. (2014). The Empire of Value: A New Foundation for Economics. (M. B. Debevoise, Trans.). Cambridge, Massachusetts: MIT Press.

Searle, J. R. (1995). The construction of social reality. London: Allen Lane.

Thompson, E. P. (1971). The Moral Economy of the English Crowd in the Eighteenth Century. Past \& Present, (50), 76-136.

Varian, H. R. (2010). Intermediate Microeconomics: A Modern Approach (8th International student edition). New York, NY: W. W. Norton \& Company.

Veblen, T. (1970). The theory of the leisure class. London: Allen and Unwin.

Zuckerman, E. W. (2012). Construction, Concentration, and (Dis)Continuities in Social Valuations. Annual Review of Sociology, 38(1), 223-245. https://doi.org/10.1146/annurev-soc-070210075241 